\title{
Thomas Lowe Bunting, M.D.
}

BonN at Heanor in Derbyshire in 1868, Dr Bunting took his degree at Edinburgh in 1889 after a distinguished career as a student. Whilst at the University he became associated with Professor Patrick Geddes's work amongst the students, then just beginning, which grew into the Town and Gown movement, and had for its object to make the students take an interest in the welfare of the poor. This interest lasted with him all through his life. After leaving Edinburgh he went first to an asylum near Buxton and thence to Newcastle where he joined the old Fabian Society, and then and always took a deep interest in all social problems.

In 1904 he proceeded to his M.D., gaining a Gold Medal for his thesis which was on the Histology of Lymphatic Glands. Little had been done in this field since the classic investigations of His, which had been accepted for so very many years. But His had made his observations on the glands of the ox, the structure of which Dr Bunting found to be peculiar to the species and very different from the arrangement really found in Man.

In 1911 he took his B.Hy. and D.P.H., both with honours, at the University of Durham; but even before this he had begun to study Radiology, and he acted to the end of his life as Radiologist to the Children's Hospital at Newcastle-on-Tyne. On the outbreak of War he was appointed Radiologist to the Northumberland War Hospital, a heavy task for a man still in general practice; but he carried out the duties with the untiring devotion which made his department in the Hospital a complete success. His published papers on Radiological subjects are masterpieces of deductive reasoning.

Of his medico-political work a colleague writes: Dr Bunting was first interested in medico-political matters through his being on the old Northumberland Contract Committee before it was taken over by the B.M.A. From this, he finally became a leading figure in the North-East of England as Secretary of the Newcastle Panel Committee and one of the elected Medical representatives on the Newcastle Insurance Committee and Secretary of the North-Eastern groups of Panel Cornmittees.

The agitation in 1912 over the National Health Insurance Act came to Dr Bunting as a call for work on behalf of the profession. This led 
to his devoting an increasing amount of thought and time to medical politics until he became in Newcastle the guide and adviser of the Panel Committee in general and of many individual doctors in particular. Dr Bunting was elected a Fellow of this Society in 1905. He died of angina pectoris on the 18th of February 1925.

J. S. M'C. and H. L. R. 